\title{
NEWS FROM EUROPE ON THE ISSUES OF INCLUSIVE POLICIES
}

\section{Martin Kaleja}

In the societal context in recent years here in Europe, an emphasis has been laid on issues concerning equality, fairness and inclusion in education. Apart from abundant discussions, advisory meeting, both professional and vocational, there are also ambivalent confrontations. Some contest the very ideas that the others support. Varying attitudinal tunings of variously defined groups of people in the society enhance, support and in some cases promote certain things equally, or even the more vociferously, the less they result in a grasp on the topic. An example is the educational community where there is no uniform perception, much less uniform implementation of inclusive education. Inclusive and integration phenomena become the subject of communication troubles despite the fact that by their nature, they should prevent conflict among stakeholders in education. The context of institutional school education of Roma children, pupils and adult Romani is exactly the same. It is conceived completely identically not only in the educational field, but especially in the context of the general social perception. This is why representatives of the Member States of Europe assembled on 10 and 11 October 2019 at the Council of Europe in Strasbourg to the $8^{\text {th }}$ meeting of the International Dialogue between the Council of Europe and the Romani and Travellers to discuss difficult issues, problems and barriers with which the Romani are faced on their educational path. They encounter restrictions, limitations, diminishment and exclusion. Educational potential in some of the Romani of preschool age is not adequately stimulated. Non-participation in preschool education causes the loss of what attendance at kindergarten, or at least at one-year preparatory class of a primary school brings to other children.

Thus, socialization of the child is diminished. Communication and language skills are not developed by the appropriate required influences. However, language is the means of communication which facilitates the processes of teaching and learning. Communication needs to develop and enrich in an ontogenetically adequate way, not all language levels and linguistic dimensions. Language and communication are mechanisms of the development of cognitive processes. Their restriction and limitation mean a loss on and significant limiting intervention into school education, and consequently, of course, also into the quality of human life.

Education is a factor that affects our whole being. By its means, an individual makes decisions, determines, chooses from offers, selects, approves and sets for themselves their own form and level of conformity of their conduct and behaviour, evaluating and assessing normality, including the question of openness to disposabilities, variations and other modalities. As evident, education is more than just a "piece of paper" in the form of a "report card", or in the form of a diploma, confirming what education 
should include in and of itself. According to available sources, almost half of Romani children of preschool age are still not participating in school education. If parents decide for the institutional form of education, the prefer elementary school preparatory classes to kindergartens (Kolaříková, 2015). Effective as of September 2017, the Education Act supposes obligatory participation in preschool education, which is implemented in terms of the Framework Educational Programmes for preschool education. Preparatory classes of primary schools have started implementing the character of preschool curriculum content since September 2016 and they are one of the possible legitimate alternatives of the realization of compulsory education fully guaranteed by the state. (Kaleja, 2019) A high number of Romani pupils gain their compulsory elementary education outside the educational mainstream. According to a survey by the Czech School Inspectorate from 2015 , the total sum of $15.1 \%(5,167)$ of all 34,191 Romani pupils from a total of 4,098 primary schools were educated under the Framework Educational Programme with reduced content and lowered demands, which in practice represents not only lowered expected outcomes of key competencies, but also doubt about the correctness of diagnostic procedures and subsequent measures taken. (Vláda České republiky, 2016) What are the visions, the trends of educational policy taking into account the peculiarities of school education of Romani children, pupils and students, in the area of the European Union? The Council of Europe together with representatives of the Romani and Travellers, as declared at their $8^{\text {th }}$ joint session on 10-11 October 2019 in Strasbourg, will be to promoting in the subsequent years:

- Change in pedagogical approaches applied in educational processes, including changing own personal approach of the educator. Configuration of the effect of teaching staff in the actual pedagogical configuration, as its current form is often far from the pedagogical paradigms.

- Change in the view of a pupil and their family context, and change of proper attribution towards the pupil.

- Support for the Romani language and its development and encouragement of its dissemination and interpretation, including the perception of its cultural attribute and perception of the importance to carry out research in the field of Romani language and literature.

- Subsequent definition of the possibilities of the mother tongue (Romani) in official communications and in the processes of schooling.

- Removing systematized errors that cause the enormous number of children and pupils to be educated outside educational mainstream, and finally focus on targeted active participation in social life and decision making.

\section{References}

Dubayová, T., \& Kožárová, J. (2018). Coping strategies of pupils with special educational needs in inclusion and their relation to school. Brno: Tribun EU. 
Kaleja, M. (2014). Determinanty edukace sociálně vyloučených žáků z pohledu speciální pedagogiky. Ostrava: Ostravská univerzita v Ostravě, Pedagogická fakulta.

Kaleja, M. (2015). (Ne)připravený pedagog a žák z prostředí sociální exkluze. Opava: Slezská univerzita v Opavě, Fakulta veřejných politik v Opavě.

Kaleja, M. (2019). Vzdělávací modul pro lektory a účastníky kurzu: Jak pracovat s dítětem, žákem s odlišnými kulturními a jinými životními podmínkami. Praha: Národní ústav pro vzdělávání.

Kaleja, M. et al. (2015). Etnografie školy jako edukační realita současnosti. Opava: Slezská univerzita v Opavě, Fakulta veřejných politik v Opavě.

Kolaříková, M. (2015). Dítě předškolního věku v prostředí sociální exkluze. Opava: Slezská univerzita v Opavě, Fakulta veřejných politik v Opavě.

Ústavní zákon č. 1/1993 Sb., Ústava České republiky. (1993).

Ústavní zákon č. 2/1993 Sb., Listina základních práv a svobod. (1993).

Vláda České republiky. (2016). Zpráva o stavu romské menšiny za rok 2015. Praha: Úřad vlády ČR.

Vláda České republiky. (2019). Zpráva o stavu romské menšiny za rok 2018. Praha: Úřad vlády ČR.

Zákon č. 273/2001 Sb., o právech příslušníků národnostních menšin a o změně některých zákonů. (2001).

Zákon č. 561/2004 Sb., o předškolním, základním, středním, vyšším odborném a jiném vzdělávání (školský zákon), ve znění pozdějších předpisů. (2004).

\section{Author}

doc. PhDr. et PhDr. Martin Kaleja, Ph.D.

Faculty of Public Policies in Opava, Silesian University in Opava

Research Centre for Social Inclusion

Bezručovo nám. 885/14, 74601 Opava, Czech Republic

martin.kaleja@fvp.slu.cz 